\title{
Adverse Drug Reactions, Power, Harm Reduction, Regulation and the ADRe Profiles
}

\author{
Sue Jordan ${ }^{1, *}$, Patricia A. $\operatorname{Logan}^{2}{ }^{(D)}$, Gerwyn Panes ${ }^{1}$, Mojtaba Vaismoradi ${ }^{3}$ \\ and David Hughes ${ }^{1}$ \\ 1 College of Human and Health Sciences, Swansea University, Swansea SA2 8PP, UK; \\ g.panes@swansea.ac.uk (G.P.); d.hughes@swansea.ac.uk (D.H.) \\ 2 Faculty of Science, Charles Sturt University, Bathurst Campus, NSW 2795, Australia; plogan@csu.edu.au \\ 3 Faculty of Nursing and Health Sciences, Nord University, 8049 Bodø, Norway; mojtaba.vaismoradi@nord.no \\ * Correspondence: s.e.jordan@swansea.ac.uk; Tel.: +44-(0)1792-518541
}

Received: 28 July 2018; Accepted: 13 September 2018; Published: 18 September 2018

\begin{abstract}
The power and influence of healthcare systems comes largely from the ability to prescribe efficacious medicine. However, medicine can sometimes cause harm rather than bring benefits. Systematically checking patients for the adverse effects of medicines, as listed in manufacturers' literature, would protect patients from iatrogenic harm, but this is rarely undertaken. We argue for the benefits of this approach using the example of the prescription of antipsychotics to older adults. Prescribing antipsychotics to control challenging behaviours associated with dementia is a controversial matter, and regulatory intervention is under discussion. Improved regulatory systems could protect against iatrogenic harm, such as over-sedation, falls, tremor, or drug-induced Parkinsonism. However, measuring the impact and outcomes of regulatory interventions has proved difficult, not least because there are rarely systematic records of all adverse effects of medicines. We indicate how regulatory initiatives to reduce antipsychotic prescribing can be supported by systematic monitoring and documentation of patients' signs and symptoms of putative adverse drug reactions. Monitoring documentation then provides the rationale and support for professionals' responses to identified problems. Longitudinal monitoring records would improve understanding of the impact and outcomes of adverse drug reactions (ADRs) on health and wellbeing, and the many costs of ADRs.
\end{abstract}

Keywords: adverse drug reactions; patient safety; nursing; medicine management; long-term care

\section{Introduction}

Improvements in population health in Western countries in the first half of the 20th century were the culmination of several factors, including improved nutrition, public health measures, and lifestyle changes [1], but gains since the 1940s are at least partly attributable to better medicine [2,3]. Antimicrobial agents, starting with the sulphonamides, vaccination programmes, and cardiovascular medicines, all contributed to significant reductions in mortality and morbidity [4-6]. Pharmaceutical advances transformed treatments in the mental health field, with antipsychotics bringing significant benefits for illness management [7-9]. Unfortunately, these benefits have been offset, to an uncertain degree, by new forms of iatrogenic disease associated with the adverse effects of prescribed medicines [10,11]. Antipsychotics have not been exempt from adverse drug reactions (ADRs), as considered in the present paper [12,13]. We reflect on the social context of prescribing, the problem of preventable ADRs, our solution, and its congruence with the logic of regulatory interventions. 


\section{Power via Prescribing}

The development of effective medicines did much to legitimise the cultural authority of the medical profession, which exercised a professional monopoly over the prescribing of a wide range of pharmaceuticals. Reflecting on the advances of the 1950s, Dr. Julian Tudor Hart explained that: 'Doctors who were previously seen as people who could only write a prescription for some cough medicine suddenly wrote a prescription for something that actually saved your life. The act of writing the prescription wasn't $[S I C]$ any more skilled in the second instance than in the first, but the effect was quite different. So doctors took a huge leap forward to becoming much, much more credible than parsons and priests as emissaries of God [SIC]' [14]. Even in an age of 'patient-centred medicine', medical professionals remain socially distant from certain sections of the population, including people with mental illness and older patients in long-term care institutions, who are the subject of this paper. Past studies have found that medical care in nursing homes is suboptimal, with poor use of psychotropic medication and shortcomings in pain management [15-17]. The near medical monopoly over prescribing means that other members of the care team are rarely as attentive to the side effects of mental health medicines as would be desirable. There is a risk that patients in care homes are disadvantaged by their 'sick role' status and unintentional 'othering' [18], and risk being labelled by their diagnoses and prescriptions, without adequate oversight of ongoing pharmacotherapeutic regimens. Ways need to be found to increase the effectiveness of medicines' monitoring by front-line care staff.

Healthcare professionals routinely underestimate harm and overestimate benefits of prescription medicines [19]. Prescribed medicines benefit between $4 \%$ and $25 \%$ of patients [20], whilst ADRs affect $7.8 \%$ of primary care patients [21], $4.8-37 \%$ of people with cognitive impairment [22], and $11.0 \%$ of hospitalised patients [23], killing $0.25 \%$ of hospitalised patients [24]. Lower figures (1.85\%) are reported in Norway, excluding events of unknown aetiology [25]. The inability to distinguish drug-induced signs and symptoms from definitive medical diagnoses tends to result in further prescriptions, increasing the risk of drug-drug and drug-disease interactions [26]. However, systematic processes to check patients for the potential adverse effects of their medicines are rarely used $[27,28]$ and consensus for usage of available tools remains remote [29].

\section{The Adverse Drug Reaction Problem}

Preventable ADRs have proved an intractable problem over the last decade, causing 5-8\% of unplanned UK hospital admissions [30,31], rising to $10 \%$ amongst older adults [32], and costing the NHS $£ 1$ bn- $£ 2.5$ bn each year [33]. ADRs assessed as due to avoidable errors are responsible for 712-22,303 UK deaths, costing $£ 98.5 \mathrm{~m}-£ 1.6$ bn each year [34]. In Australia, $15 \%$ of admissions of older people (aged 72-88 years) are due to ADRs, $92 \%$ of which are preventable [35], and admissions related to all types of ADRs are associated with $28-32 \%$ longer hospital stays [36]. The problem is at least as extensive in developing countries, at $\sim 10 \%$ of admissions [37]. However, $\sim 60 \%$ of adverse drug events are not recognised and reported as such, which suggests that these figures may be an underestimate [38], and higher figures (11\%, $18 \%$ and $19.6 \%$ in the elderly), are quoted [21,39-41]. Most ADRs, adverse drug events (ADEs), and medicine mismanagement (including errors by patients and professionals) are preventable [21,30,31], particularly with additional enhanced monitoring [30,31,42-47], but comprehensive systematic multiprofessional approaches are needed to address the problem $[27,28]$ (Table S1).

\section{Antipsychotics, Challenging Behaviour and Older Adults in Care Homes}

Some $50 \%$ of residents in UK care homes are prescribed mental-health medicines [48]. Doses in care homes [49] and primary care [16] are often excessive, and the proportion of care home residents exposed to inappropriate medications ranges from 34\% [50] to $>50 \%$ [51]. ADRs as a result of mental-health medicines can be life-threatening (e.g., cardiac arrhythmias, cardiac hypofunction), or debilitating (e.g., drug-induced Parkinsonism, ataxia, postural hypotension), or subtle, and mistaken 
for signs of ageing or underlying pathology. They can be overlooked, leading to behaviour problems, xerostomia, constipation, poor food and/ or fluid intake, tremor, restlessness, sedation, pain, double incontinence, or other problems, all causing potential loss of comfort and dignity [27,52].

The excess dose-related mortality and incidence of strokes associated with antipsychotics [53] have long been concerns. In a trial of withdrawal of antipsychotics, 25/83 (30\%) patients taking antipsychotics and 48/82 (59\%) taking placebos survived 36 months [54]. Between 1 in 8 and 1 in 29 people with dementia prescribed antipsychotics suffered a stroke [55]. Drug-induced Parkinsonism occurred in 2-12\% patients, and sedation in 15-24\% [56]. A consensus is emerging around overprescribing $[16,50,51,57-60]$. However, there is no consensus regarding the changes needed to routine care [61-65], and reviewers indicate that evidence for single-profession interventions is equivocal [66], of low quality [21,67], or uncertain [66,68-71]. The UK Department of Health's National Dementia Strategy [16], launched in 2009, and the Medicines and Healthcare products Regulatory Agency (MHRA) recommendations [72], have not reduced antipsychotic prescribing in care homes [73], and prescribing of atypical antipsychotics has increased across primary care [74], warranting a closer review of regulatory interventions. Evidence collated for the recent Welsh Government (WG) report [62] showed widespread concern about the continuing overuse of antipsychotics (Box 1).

During 2017 and 2018, the Health, Social Care and Sport Committee of the Welsh Government, chaired by Dr D. Lloyd, collected evidence and made 11 recommendations to 'protect some of our most vulnerable citizens'. The report concludes: Antipsychotic medicines are being prescribed inappropriately, in many cases as a first option rather than a last resort, to treat the behavioural and psychologic symptoms of dementia, often without adequate reviews or records being kept p.61. Testimonies included:

“... where you have somebody with behavioural or psychological problems relating to their dementia, to routinely prescribe an antipsychotic medication without looking at what is underpinning those behaviours and causing them is wrong, and it does seem to be the default position, which needs to be addressed." Alzheimer's Society Cymru, p. 17.

"It is quite simply unacceptable that antipsychotic medication is still being used as a primary response to 'challenging' behaviour across many residential care services." Older People's commissioner, Wales, p. 17.

"I'd like to see the circumstance whereby people are not caught in this dreadful repeat prescription mechanism, whereby it rolls on and on and on, and you could go for two years and nobody refers to it. Some GPs, some practices, are better at reviewing than others. But, theoretically, because you're caught up in this repeat prescription mechanism, it could carry on and on and on. I'd like to see-if you're prescribed an antipsychotic and you have a diagnosis of dementia, there should be a three-month mandatory review." Care Forum Wales, p. 29.

Box 1. Use of Antipsychotics in Care Homes: A Report from the National Assembly for Wales.

\section{What Should Be Done Differently?}

Identification of medicine-related incidents as the most prevalent source of unsafe primary care in Wales and England underlines the urgency of the problem [75]. Most ADRs, adverse drug events (ADEs), or side-effects are due to poor monitoring, not poor prescribing [30,31,42-46], and are dose-related [47].

The risk of iatrogenic harm could be addressed as an integral part of individual patient care. Patients need to be systematically monitored or checked for the signs and symptoms of 'undesirable' effects as listed in manufacturers' literature. To this end, we have developed a nurse-led approach to medicines' monitoring (Box 2). This multidisciplinary intervention is important to complement regulatory initiatives in this area. Searches and reviews indicate there is no alternative comprehensive, systematic patient assessment of problems potentially related to prescribed medicines [28,42,76,77]. We are unaware of a similar outcome-monitoring approach adopted in Norway or Australia [78]; a pharmacist-led de-prescribing education initiative in Australian care homes reduced antipsychotic prescriptions, but not adverse outcomes [79]. 
Our intervention, the Adverse Drug Reaction (ADRe) Profile asks nurses to systematically check patients for the manifestation of itemised adverse side effects or undesirable effects of their mental health medicines, as listed in the British National Formulary and manufacturers' Summaries of Product Characteristics (SmPCs), action problems identified, and share the Profile with pharmacists and/or prescribers. This is a formalised and standardised approach to monitoring all patients prescribed mental health medicines, regardless of diagnostic categories. The ADRe Profile comprises: vital signs, and changes in vital signs, observations, focussed questions or reports of possible ADRs, prevention / health promotion areas likely to be affected by medicines, including diet, medicine use, service user's perspectives, and care plan modifications (http:/ / www.swansea.ac.uk/adre/requestforadretool/) (Figure 1). Nurses pass the completed profile with problems highlighted to pharmacists and prescribers to inform medication review. The supporting information suggests which medicines or conditions might be causing the indicated problems and what further information might be of assistance (Figure 2). The list of problems is then juxtaposed with the medicines' record, and the multidisciplinary team determine possible aetiologies of problems identified, and whether medicines need to be changed.

The ADRe Profile for mental health medicines was introduced to address nurses' and patients' concerns that ADRs were neither recognised nor communicated to prescribers. The benefit of listing problems in one document, which can be passed to prescribers reviewing medication, is that these problems then get addressed, doses of antipsychotics and sedatives are reduced, and patients' signs and symptoms resolve. Our trials provide evidence that ADRe works [27,80], supported by other studies [81-84] (Table 1). ADRe and its supporting information empower nurses by a democratisation and transfer of useful, necessary, and practical knowledge of pharmacotherapeutics and medicine to nurses [85-87]; it was developed in Wales, a country with egalitarian traditions [88].

\section{Limitations of the ADRe Studies}

\section{Generalisation}

ADRe was developed in post-industrial South West Wales. Findings from a small European country, where most of the population are in an EU convergence zone (GDP $<75 \%$ of the EU mean), cannot necessarily be extrapolated to different populations. Without further studies to confirm transferability, generalisation of findings depends on logical inferences. However, medicine mismanagement is an international problem, in urgent need of effective interventions [89].

\section{Volunteer Bias}

We acknowledge the potential for volunteer bias in all research designs. Only policy initiatives can determine whether our findings will transfer to struggling organisations, as they are unlikely to volunteer for research projects, and may be less likely to have sufficient staff to offer support to those withdrawing from medicines. Participant recruitment to our studies was at the discretion of nurses, and we cannot discount the possibility of selection bias.

\section{Nurses' Reporting}

ADRe relies on nurses' reports; some care home residents are non-verbal and some mental health service users lack communication skills [84]. ADRe is vulnerable to nurses' interpretations, and we acknowledge that nurses may under-report patients' ADRs [76]. Although $~ 50 \%$ of ADRe items can be identified in care homes' notes, the information takes $\sim 1 \mathrm{~h}$ to retrieve [27], and prescribers are limited to 7-15 min per patient. Therefore, ADRe increases the information passed to prescribers.

\section{Time Needed to Complete ADRe}

Initially, ADRe asks nurses or their assistants to do more work by spending 10-30 min documenting problems with each patient, and acting on problems identified; we estimate this costs $£ 20$ [27], which can only be compensated by reduction in patients' demands following improved patient welfare. This initial barrier to uptake usually recedes with familiarity and regular use. If problems are addressed, patients benefit, medicines are optimised, and patients are calmer (Table 1); these clinical improvements persuade nurses to continue with ADRe. The diversion of resources to ADR management may be cost-effective [77], but further work is needed to explore any unintended consequences, such as neglect of other documentation.

\section{Evaluating the Outcomes of ADRe}

ADRe is comprehensive, with $\sim 80$ items, most of which are clinically important. Therefore, rather than defining a single 'outcome measure', we have used a composite 'number or problems identified and addressed', and described clinical gains. Table 1 has illustrative examples. 


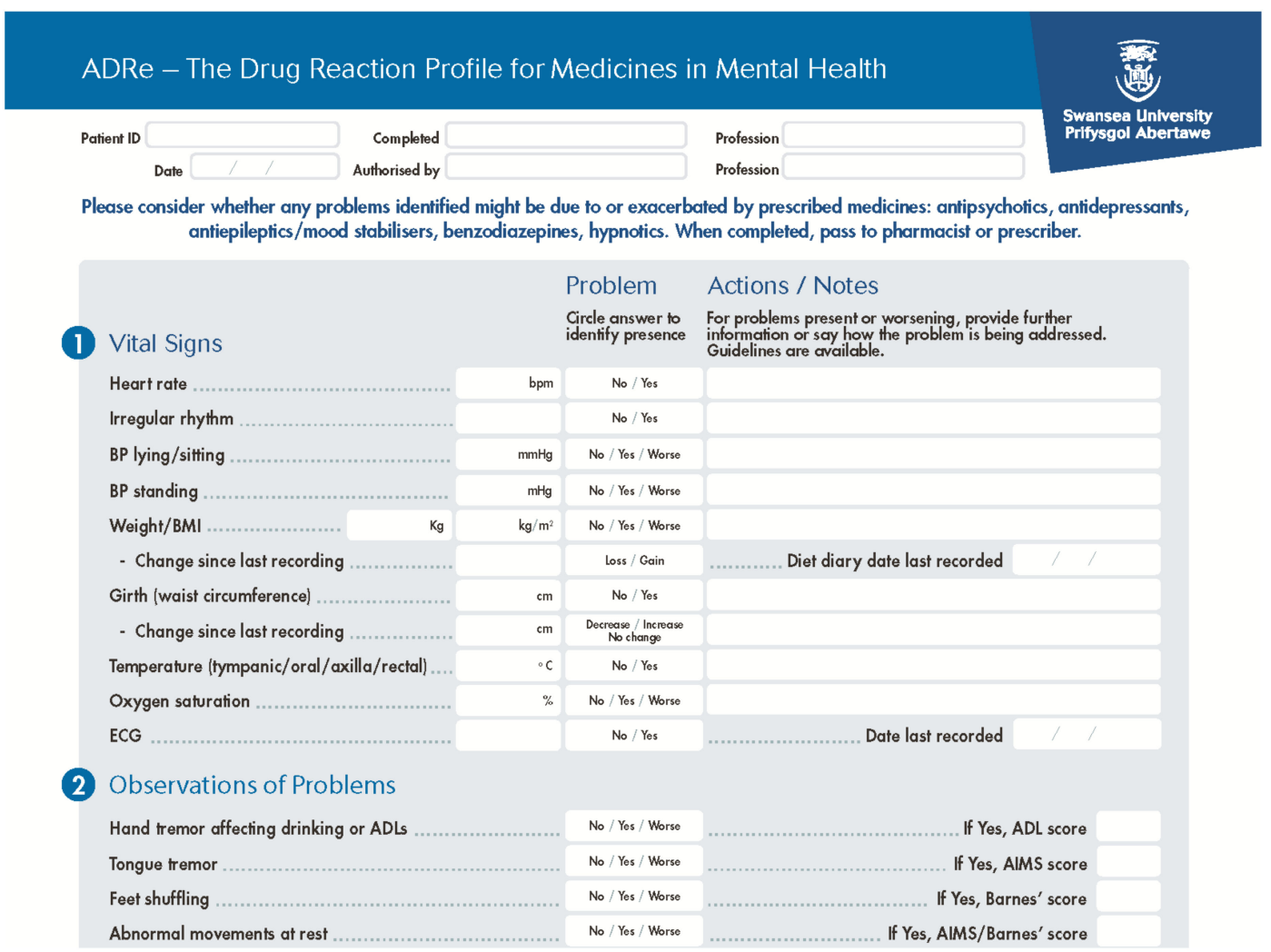

Figure 1. An illustration of the Adverse Drug Reaction (ADRe) Profile for mental health medicines. These are the first questions on the ADRe Profile. This is accompanied by a 'How to Use' sheet, and supporting information (Figure 2). To request a copy of ADRe, visit: http:/ /www.swansea.ac.uk/adre/. 


\begin{tabular}{|c|c|}
\hline & VITAL SIGNS \\
\hline OBSERVATIONS & COMMENTS/ACTIONS \\
\hline Heart rate & $\begin{array}{l}\text { Please review information on assessing: } \\
\text { Normal range is } 50-90 \text { beats per minute (bpm). } \\
\text { If a problem or concern is detected: } \\
\text { Heart rate }<50 \text { of }>130 \text { bpm is potentially urgent: recheck within } 5 \text { minutes, } \\
\text { refer to doctor. } \\
\text { Slow heart rate, consider drugs for dementia (donepezil, galantamine, } \\
\text { rivostignmine), beta blockers, opioids, beta blockers, digoxin, } \\
\text { hypothyroidism, heart disease or long-term pain. } \\
\text { Fast heart rate, consider recent exercise, stress, fever, bronchodilators } \\
\text { (beta2 agonists e.g., salbutamol, formoterol), antimuscarinics (e.g., } \\
\text { oxybutynin, hyoscine, full list under 'cognitive decline', below), clozapine, } \\
\text { hyperthyroidism (or excess thyroxine), pain, anaemia, heart disease, } \\
\text { stimulants prescribed for attention deficit hyperactivity disorder (e.g., } \\
\text { methylphenidate), and non-prescribed stimulants e.g., cold cures, } \\
\text { recreational drugs, including amphetamines, cocaine, caffeine, alcohol, } \\
\text { tobacco, solvents. } \\
\text { If heart rate rises by >10\% on standing, this indicates dehydration, } \\
\text { particular concern if diuretics prescribed. } \\
\text { Reference values from Royal College of Physicians ( } 2012 \text { ). }\end{array}$ \\
\hline
\end{tabular}

Figure 2. An example of ADRe's Supporting Information. If a problem is identified, nurses are asked to review the supporting information for that problem, and consider the actions suggested. The suggested aetiologies should be discussed within the multidisciplinary team. 
Table 1. Studies on the ADRe Profiles.

\begin{tabular}{|c|c|c|c|c|}
\hline & Design & Clinical Area & Findings & $\begin{array}{l}\text { Case Reports, Examples of ADRs Addressed } \\
\text { without Hospitalisation }\end{array}$ \\
\hline \multicolumn{5}{|c|}{ Studies Using the ADRe Profiles } \\
\hline Jones et al. 2016 [81] & $\begin{array}{l}\text { 'Before-and-after' study of } \\
20 \text { patients }\end{array}$ & $\begin{array}{l}\text { Community mental health, } \\
\text { crisis resolution home treatment }\end{array}$ & $\begin{array}{l}\text { The Profile identified previously unreported physical health } \\
\text { problems for all participants, including two previously } \\
\text { unreported potentially life-threatening problems } \\
\text { (cardiac arrhythmia, and valproate-induced pancreatitis). In all, } \\
4 \text { participants had medicines discontinued, } 3 \text { were referred to } \\
\text { consultant psychiatrists, } 3 \text { to general practitioners, } 1 \text { to ECG } \\
\text { technicians, and } 1 \text { to dentists. Previously neglected health } \\
\text { promotion issues were also recognised. }\end{array}$ & $\begin{array}{l}\text { A middle-aged man, diagnosed with schizophrenia, had } \\
\text { previously unrecorded but potentially serious cardiovascular } \\
\text { problems (cardiac arrhythmia, intermittent acute chest pain) that } \\
\text { worsened with exertion and radiated. He was referred } \\
\text { immediately to his G. The consultant determined that this case, } \\
\text { and one other, fulfilled the criteria for a serious ADR, as it would } \\
\text { have resulted in hospitalisation if unattended. }\end{array}$ \\
\hline Jordan et al. 2015 [27] & $\begin{array}{l}\text { Stepped wedge randomised } \\
\text { controlled trial (RCT) over } \\
7 \text { months, } 5 \text { homes, } \\
41 \text { participants, } 125 \text { record } \\
\text { reviews before Profile } \\
\text { implementation and } \\
124 \text { after }\end{array}$ & $\begin{array}{l}\text { Care home residents with } \\
\text { permanent } \\
\text { cognitive impairment }\end{array}$ & $\begin{array}{l}\text { Profile administration increased the number of problems } \\
\text { addressed from a mean of } 6.02 \text { [SD 2.92] to } 9.86 \text { [4.48], effect size } \\
3.84,95 \% \text { CI } 2.57-4.11, p<0.001 \text {. For example, pain was more } \\
\text { likely to be treated (adjusted Odds Ratio (aOR) 3.84, } 1.78-8.30) \text {, } \\
\text { and more patients attended dentists and opticians (aOR 52.76 } \\
\text { (11.80-235.90) and } 5.12 \text { (1.45-18.03), respectively). Profile use was } \\
\text { associated with reduction in mental health medicines (aOR 4.45, } \\
1.15-17.22 \text { ). }\end{array}$ & $\begin{array}{l}\text { A lady in her late } 80 \text { s, diagnosed with dementia at first } \\
\text { administration of the Profile, was noted to be aggressive, restless, } \\
\text { confused, sedated, and agitated. The ADRe Profile helped staff } \\
\text { identify that hyoscine might be the cause. } \\
\text { Hyoscine was discontinued. By the end of the study, } 5 \text { months } \\
\text { later, aggression, restlessness, and sedation were no } \\
\text { longer problems. }\end{array}$ \\
\hline Jordan et al. 2014 [82] & $\begin{array}{l}\text { Feasibility study, } 11 \text { patients' } \\
\text { records reviewed } 3 \text { times } \\
\text { (before Profile } \\
\text { implementation, after, } \\
\text { and } 3 \text { months later), } \\
3 \text { homes. } \\
\text { Feedback from clinicians }\end{array}$ & $\begin{array}{l}\text { Care home residents with } \\
\text { permanent } \\
\text { cognitive impairment }\end{array}$ & $\begin{array}{l}\text { The Profile took } 20-25 \mathrm{~min} \text { to implement, caused no harm, } \\
\text { and supplemented usual care. On first use, the Profile identified } \\
\text { previously undocumented problems for all service users: mean } \\
12.7 \text { [SD 4.7]. One month later, a mean of } 4.9 \text { [3.6] problems had } \\
\text { been ameliorated. Clinical gains documented included: new } \\
\text { prescriptions to manage pain (2 participants), psoriasis (1), } \\
\text { Parkinsonian symptoms (1), rash (1); dose reduction of } \\
\text { benzodiazepines for one service user; new care plans for oral } \\
\text { hygiene, skin problems, and constipation. }\end{array}$ & $\begin{array}{l}\text { A lady in her mid- } 60 \text { s, diagnosed with 'Korsakoff's syndrome' } \\
\text { and psoriasis, was noted to be oversedated. Benzodiazepine and } \\
\text { antipsychotic prescribing were reduced, and sedation was no } \\
\text { longer a problem at follow up. Itching rashes were also identified, } \\
\text { more creams were administered, including an 'as needed' } \\
\text { prescription for hydrocortisone, and symptoms were ameliorated. }\end{array}$ \\
\hline Gabe et al. 2014 [80] & $\begin{array}{l}\text { Parallel group RCT } \\
\text { Researcher observed clinical } \\
\text { visits before and after } \\
\text { implementation of the } \\
\text { Profile in the } \\
\text { intervention arm. } \\
\text { Feedback from patients } \\
\text { and clinicians }\end{array}$ & $\begin{array}{l}\text { Respiratory medicine, } \\
\text { outpatient department, } \\
54 \text { patients recruited and } \\
\text { followed up }\end{array}$ & $\begin{array}{l}\text { The increase in numbers of problems per participant identified at } \\
\text { follow up was significantly higher in the intervention arm where } \\
\text { the median change was }+20.5 \text { (inter-quartile range (IQR) 13-26) } \\
\text { while that in the control arm was }-1(-3 \text { to }+2 \text { ) (Mann-Whitney } \\
\mathrm{U} \text { test: } \mathrm{z}=6.28, p<0.001) \text {. The increase in numbers of actions per } \\
\text { participant taken at follow up was significantly higher in the } \\
\text { intervention arm, where the median increase was }+2.5(1-4) \text {, } \\
\text { while that in the control arm was } 0(-1.75 \text { to }+1 \text { ) (Mann-Whitney } \\
\mathrm{U} \text { test: } \mathrm{z}=4.40, p<0.001) \text {. }\end{array}$ & $\begin{array}{l}\text { Without the Profile, no actions were taken by nurses for a lady in } \\
\text { her } 50 \text { s, with respiratory problems sufficiently severe as to } \\
\text { warrant oral prednisolone. Using the Profile, nurses advised her } \\
\text { to contact her GP to seek advice regarding mood swings, } \\
\text { depression, headaches, and immunisations. The nurse } \\
\text { commented: "I would not have picked up on x's depression } \\
\text { without the Profile". }\end{array}$ \\
\hline Gabe \& Jordan 2014 [83] & $\begin{array}{l}\text { Inter-rater reliability Profiles } \\
\text { completed in the presence of } \\
\text { an observer }\end{array}$ & $\begin{array}{l}\text { Respiratory medicine, } \\
\text { outpatient department, } \\
48 \text { patients prescribed } \\
\text { respiratory medicines }\end{array}$ & $\begin{array}{l}\text { Cohen's } \kappa \text { for inter-rater reliability for each item ranged } 0.73-1 \\
\text { (good to complete agreement). The Profile identified previously } \\
\text { unsuspected problems in all participants, including muscular } \\
\text { weakness, skin, and mouth problems. }\end{array}$ & $\begin{array}{l}\text { A lady in her 70s prescribed corticosteroids, bronchodilators, } \\
\text { and other respiratory medicines, reported multiple oral problems, } \\
\text { plus losing two stone in weight over the last six months, because } \\
\text { her mouth was too sore to eat comfortably. She was advised to } \\
\text { rinse her mouth shortly after each inhaler use, seek advice from } \\
\text { the nurse for information on inhaler technique, and maintain } \\
\text { routine dental check-ups. }\end{array}$ \\
\hline Jordan et al. 2004 [76] & $\begin{array}{l}\text { Comparison of instruments } \\
\text { available to monitor } \\
\text { antipsychotic medicines. } \\
\text { Inter-rater reliability, } \\
20 \text { Profiles completed in the } \\
\text { presence of an observer }\end{array}$ & $\begin{array}{l}\text { Community mental health } \\
\text { teams, } 20 \text { service users } \\
\text { prescribed long-term medicines }\end{array}$ & $\begin{array}{l}\text { The ADRe Profile assessed a broader range of physiological } \\
\text { parameters and potential problems than other instruments. It is } \\
\text { the only instrument with supporting information to prompt } \\
\text { action in routine care. } \\
\text { Items on the Profile had moderate-to-complete inter-rater } \\
\text { reliability (ranging 0.44-1.00) }\end{array}$ & NA \\
\hline
\end{tabular}


Table 1. Cont

\begin{tabular}{|c|c|c|c|c|}
\hline & Design & Clinical Area & Findings & $\begin{array}{l}\text { Case Reports, Examples of ADRs Addressed } \\
\text { without Hospitalisation }\end{array}$ \\
\hline Jordan et al. 2002 [84] & $\begin{array}{l}\text { 'Before-and-after' study } \\
\text { with } 1 \text { intervention and } \\
1 \text { comparator group }\end{array}$ & $\begin{array}{l}3 \text { community mental health } \\
\text { teams in post-industrial South } \\
\text { Wales, } 40 \text { service users } \\
\text { prescribed long-term mental } \\
\text { health medicines }\end{array}$ & $\begin{array}{l}\text { Amongst the } 20 \text { clients in the intervention group, the Profile } \\
\text { highlighted several problems, two of which were urgent. In the } \\
\text { intervention group, the mean number of problems actioned per } \\
\text { client increased from } 0.35 \text { (range }=0-4) \text { without the Profile to } 3 \\
\text { (range }=0-6) \text { with }(z=-3.747,2 \text { tailed } p<0.001) \text {. Nurses offered } \\
\text { appropriate advice or encouraged clients to contact the relevant } \\
\text { agencies to resolve the physical health problems identified. In the } \\
\text { comparator group, the number of problems actioned declined } \\
\text { from } 0.85(0-3) \text { to } 0.5(0-2) \text {, a statistically insignificant difference } \\
(\mathrm{z}=-1.47, p=0.14) \text {. }\end{array}$ & $\begin{array}{l}\text { Of } 20 \text { clients in the intervention group: } \\
\text { - One had coupled beats, and was urgently referred to the } \\
\text { prescriber, who immediately reduced the dose of the } \\
\text { antipsychotic depot. } \\
\text { One had severe hypertension, } 200 / 120 \mathrm{mmHg} \text {, and was } \\
\text { immediately referred to his general practitioner (GP), } \\
\text { and subsequently to renal physicians. } \\
\text { Two had postural hypotension. They were encouraged to } \\
\text { maintain adequate fluid intake. Notes were attached to the } \\
\text { medical notes to alert the psychiatrist. } \\
\text { Six had a degree of hypertension, above } 140 / 90 \mathrm{mmHg} \text {. } \\
\text { Measurements were repeated at three subsequent } \\
\text { clinic visits. Five clients were advised to contact their GPs, } \\
\text { one refused. The 6th client was being investigated for } \\
\text { a cerebral tumour. } \\
\text { Inflation of the cuff revealed marks of intravenous injections } \\
\text { on the forearm of one client. There were no previous records } \\
\text { of substance misuse.. }\end{array}$ \\
\hline Jordan 2002 [85] & $\begin{array}{l}\text { 'Before-and-after' study } \\
\text { with intervention and } \\
\text { comparator groups, } \\
40 \text { patients. } \\
\text { Interviews with } \\
\text { professionals and } \\
\text { service users }\end{array}$ & $\begin{array}{l}\text { Community mental health } \\
\text { teams in post-industrial } \\
\text { South Wales }\end{array}$ & $\begin{array}{l}\text { Profiles apportioned aspects of medication management between } \\
\text { nurses and medical presscribers. Most actions taken by nurses to } \\
\text { alleviate adverse effects concerned clients' physical health and } \\
\text { advice on health-promotion. Nurses' interventions would have } \\
\text { been more effective had they been able to supply clients with } \\
\text { certain medicines, for example for sunblock or oral care. } \\
\text { For some clients, ameliorating the adverse effects of medication } \\
\text { would have involved changes to prescribed antipsychotic } \\
\text { medication; here, decisions were more equivocal. }\end{array}$ & $\begin{array}{l}\text { One client was referred to his GP with chest pain; since he was } \\
\text { receiving } 100 \mathrm{mg} \text { fluphenazine decanoate per week, the absence of } \\
\text { an ECG recording contravened current guidelines. } \\
\text { Nurse: You can attach this to the notes. Show the psychiatrist } \\
\text { a copy. If you took the time to take it to the psychiatrist-it } \\
\text { could work. (...) By using this we'll have more evidence to show } \\
\text { that there are side effects and we're concerned, to get } \\
\text { medication reviewed. Outpatient appointments are very 'in and } \\
\text { out' and things get missed. }\end{array}$ \\
\hline \multicolumn{5}{|c|}{ Studies undertaken before the Profile was introduced } \\
\hline Jordan et al. 2000 [86] & $\begin{array}{l}\text { Stakeholder interviews and } \\
3 \text { service user focus groups }\end{array}$ & $\begin{array}{l}\text { Mental health nursing: } 7 \text { service } \\
\text { user representatives, } 3 \text { service } \\
\text { user focus groups }\end{array}$ & $\begin{array}{l}\text { Service users described serious shortfalls in professionals' } \\
\text { abilities to inform them of common adverse effects of medication; } \\
\text { these problems were attributable to inadequate } \\
\text { educational preparation. }\end{array}$ & $\begin{array}{l}\text { User group representative: CPNs (Community Psychiatric } \\
\text { Nurses) focus on the psychiatric illness, they don't see the } \\
\text { medical side, or want to become involved. It's to do with } \\
\text { their training. They wouldn't help with the constipation or the } \\
\text { sunburn for my daughter. This should be in their training. }\end{array}$ \\
\hline Jordan et al. 1999 [87] & $\begin{array}{l}\text { Interviews, observations, } \\
\text { and questionnaires with } \\
14 \text { community mental } \\
\text { health nurses. }\end{array}$ & $\begin{array}{l}\text { Community mental } \\
\text { health teams }\end{array}$ & $\begin{array}{l}\text { Service users were experiencing ADRs, but nurses did not have } \\
\text { a structure to record and report problems. Doctors were seeking } \\
\text { information from nurses, rather than directly from service users. }\end{array}$ & $\begin{array}{l}\text { Nurse: There should be a form of structure for it } \\
\text { (client education). I's down to individuals whether or not they } \\
\text { see the importance of educating people regarding their } \\
\text { medication, and I think that should be part and parcel of } \\
\text { the assessment. I think it should be there, and I know that it's not, } \\
\text { from my own experience. To me, whoever is on medication, I will } \\
\text { ask them if they understand their medication. People say } \\
\text { "Oh well, that's the GP's role, that's the doctor's role", but it isn't. } \\
\text { It isn't done and I always ask them that question, "Do you } \\
\text { understand what your medication's doing?", and I suppose my } \\
\text { knowledge maybe ins't enough either, and I think that maybe I } \\
\text { need more training to carry that further. (...) We've got to be } \\
\text { prepared to answer questions-informed answers have got to be } \\
\text { given, then people will ask, 'What's this for, what's this supposed } \\
\text { to do to me?' (...) }\end{array}$ \\
\hline
\end{tabular}




\section{Regulatory Interventions to Modify Prescribing and Outcomes}

It remains to be seen how regulatory interventions will address the problems outlined and be placed in the public domain. However, there are no guarantees that regulatory interventions will improve the processes and outcomes of care, and structures are needed to pre-empt regulatory failure. Our logic model outlines the process of change-actions, beliefs, processes and outcomes-and possible unintended consequences (Figure 3).

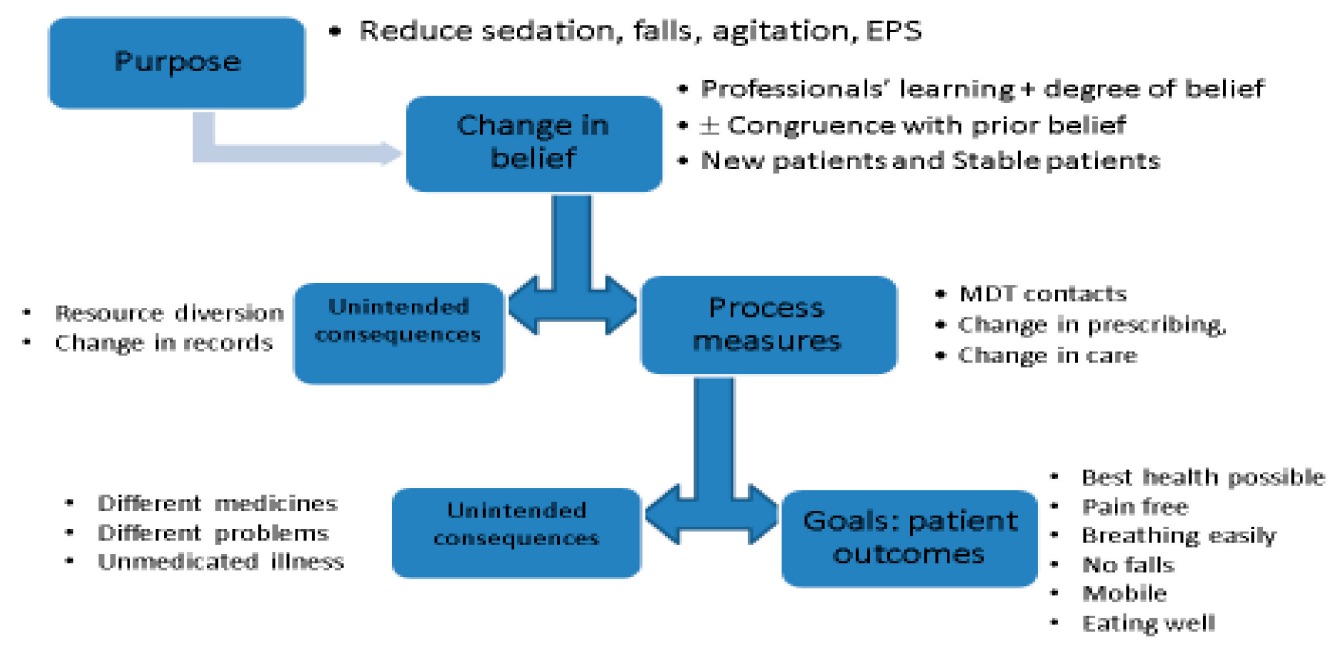

Figure 3. Logic Model for the introduction of regulation to reduce prescribing of antipsychotics to older adults. Real-world changes may follow a logic model of resources/actions/process change/outcome change (The Kellogg Foundation 1998). In any mandated intervention, there is an opportunity cost, and each phase may be associated with unintended consequences.

\subsection{Actions}

While some regulatory actions are as straightforward as product withdrawal, many restrictions are complex, and therefore more difficult to target and monitor. For example, while prescribers are advised to restrict doses of paracetamol for people weighing $<60 \mathrm{~kg}$, and restrict further for those $<50 \mathrm{~kg}$ [90], medicines are often prescribed without knowing patients' current weight. Unless information on weight is passed to the prescriber, using ADRe or similar documentation, ascertaining such detail may be time-consuming, which results either in the restriction being overlooked or in the product falling out of favour. Many cautions and contraindications apply to subgroups; however, patients move between categories by aging, developing cardiovascular risk factors, or becoming pregnant. There is little indication that pre-emptive surveillance is widely undertaken, particularly in preconception care [91]. If de-prescribing is incongruent with prior beliefs of clinician or patient, change may be resisted and difficult [92]. Where regular monitoring is mandated, products may fall out of favour if the monitoring is thought to be too onerous (see 'switching', below).

\subsection{Change in Belief}

Patients' attitudes and commitments to their therapeutic regimen may influence prescribing: For example, a time series analysis found that admonitions had no impact on prescribing of opioids, intimating that patient preference or dependence may be influential [93]. Prescribers' degree of belief in new evidence or interventions will determine transfer of evidence to individual patients, as is recognised by advocates of evidence-based medicine: research evidence can inform, but can never replace individual clinical expertise, and it is this expertise that decides whether the external evidence applies to the individual patient, and if so, how it should be integrated into a decision ([94], p. 72). The risks of unmedicated illness may override the risks of ADRs: for example, the prescription of antiepileptics was unaffected by warnings of suicidality [95]. Consultant psychiatrists responsible for 
clients with histories of severe mental illness, sometimes including homicides, are reluctant to change therapeutic regimens, despite disabling ADRs [84]. Systematic completion of a standard instrument like the ADRe Profile offers prescribers a record of all drug-related harms and symptoms of mental illness, such as irritability and hallucinations, and physical illness, such as chest pain and dyspnoea, to assist decision-making.

\section{Learning and Unintended Learning}

While regulation is directed at prescribing, there may be unintended impacts on other behaviours. Warnings of the impact of leukotriene receptor antagonists on mood and behaviour (aggression/hostility) increased prescriber and patient awareness, resulting in a rise in mental health contacts from 8.32 to $8.93 \%$ /month in adults, and suicide attempts from 0.06 to $0.09 \%$ in those aged 18-29 [96]. Spontaneous reporting overlooks $~ 95 \%$ of ADRs [97], leaving the data vulnerable to bias. Regulatory warnings increase spontaneous reporting, intensifying respondent and notoriety biases. For example, osteonecrosis of the jaw in 81 patients co-exposed to bisphosphonates and chemotherapy and/or corticosteroids was attributed solely to bisphosphonates [98]. In the French pharmacovigilance database, reports of adverse events rose in the 2 years following warnings; for example, reports of rhabdomyolysis more than doubled after this issue was highlighted in 2001 [99]. Increases in spontaneous reporting may reflect healthcare professionals' learning, rather than real increases in ADRs $[98,99]$. ADRe depends on regular, routine monitoring, rather than spontaneous reports.

\subsection{Processes of Care}

Prescribers' and service users' degree of belief, learning, and commitment to therapeutic intervention influence process measures, such as changes in prescribing, checking patients for restrictions, and engaging in close monitoring. Changes are contextualised by prior beliefs, entrenched attitudes, and perceptions of what is considered feasible and achievable [100].

\section{Unintended Processes}

Both service users and professionals may 'work round' restrictions or mandated monitoring. Where medicines are restricted or restrictions are seen to be inconvenient, patients may turn to buying over the internet. Alternative remedies may be sought from herbalists, suppliers of other complementary medicines, or even suppliers of recreational drugs. Anecdotally, where prescribers refuse to supply procyclidine to users of antipsychotic medicines, service users purchase this from street dealers or resort to feigning the signs of dystonia to prompt nurses to administer procyclidine under PRN (pro re nata or as needed) prescriptions. The UK's Quality Outcomes Framework (QOF) aimed to link general practitioners' (GPs) pay to quality of care [101]. This was expanded in 2006 to include completion of a questionnaire assessment of symptoms of depression, aimed at targeting prescribing to those more severely depressed [102]. However, this requirement for additional documentation was circumvented by using symptom rather than diagnostic codes [103].

Regulation may promote therapeutic substitution or switching. Additional regulatory requirements may encourage switching to (more expensive) medicines where patient monitoring is not mandated. For example, the prescription of factor Xa inhibitors increased between 2010 and 2014 [104], due, in part, to the reduced need to attend anticoagulation clinics [105]. Substitution of diclofenac for coxibs increased the use of diclofenac, until the recognition of the dose-response association of this medicine with cardiovascular events [106], and subsequent withdrawal from pharmacy sale [107].

Switching may not be problem-free. In the USA, guidelines to reduce prescribing of antipsychotics for older adults resulted in increased prescribing of benzodiazepines (adjusted Odds Ratio (aOR) 3.05, 1.17-7.94) and anti-dementia medicines (aOR 1.98, 1.12-3.50), but little change in use of antipsychotics (aOR 0.83, 0.37-1.89) $(\mathrm{n}=331)$ [108]. ADRe aims to be comprehensive, capturing the undesirable effects of sedatives and other medicines, so it continues to be useful after therapeutic substitution to assess change or the emergence of different adverse effects. 


\subsection{Outcomes of Care}

Changes to the processes of care do not necessarily improve outcomes. Outcomes, particularly mortality, are heavily confounded by lifestyle and genetic factors. Implementation of the UK's QOF, associated with large monetary incentives, did not significantly improve mortality [109].

More comprehensive data are needed to capture all consequences of prescribing and regulatory change to minimise risk. Approximately $50 \%$ of mundane problems, such as constipation, xerostomia, dizziness, and incontinence, which may be drug-related, remain incompletely documented, reducing the likelihood of identifying both harms and benefits, unintended and intended, in practice and in pharmacovigilance database work [110]. Most ADRs are not medically serious, but these mundane problems, from incontinence to xerostomia, negatively impact quality of life or adherence to therapeutic regimens. Such problems are not medically interesting (an inverse interest law), and are only captured by proper surveillance. Direct questioning by professionals doubles the number of adverse drug events identified [111]. Primary care pharmacist questioning identified problems in 168/180 patients, for example, xerostomia, sweating, diarrhoea, constipation [112]. ADR reporting in clinical trials using standard questions and diary cards increased ADR reporting, for example, from 1.5-5.1\% to $29-49 \%$ [113]. In USA primary care, $18 \%$ (394/2248) of patients reported ADRs to researchers, but only 3\% (64) had previously had these documented [114]; incontinence and headache are among problems least likely to be documented [115]. When considered together, the diverse pharmacist-led medication therapy management programmes improve medication appropriateness, adherence, and dosages, but there is little evidence for their effectiveness in identifying and resolving drug therapy problems [71]. Nurse-led direct questioning using ADRe increased the mean number of problems recorded from 7.30 [SD 3.18] per participant to 15.81 [SD 5.90], and outcomes such as pain and falls improved [27]. The ADRe Profile addressed serious ADRs in $10 \%$ patients in mental health teams $[81,84]$, and in care homes $[27,82]$.

\section{Unintended Outcomes}

The diagnostic uncertainty and social contingency inherent in recognition of unintended consequences suggest the need for more comprehensive, targeted data collection. Uncertainties surrounding complex restrictions are compounded by social and geographical distance between prescriber and patient, patients' and professionals' expectations (the Rosenthal effect), the mundane nature of many ADRs, and confounding by indication, co-prescription, or socioeconomic status. These impact on patients' opportunities to report problems, the number and nature of problems recorded, and availability of data. Recognition is particularly difficult where outcomes are transgenerational, beyond the immediate neonatal period (education), or in vulnerable subgroups (e.g., co-exposed, polymedicated, immunosuppressed, or genetically vulnerable).

Where medicines are changed or discontinued, unmedicated illness may emerge. The concerns regarding valproate increased prescribing of lamotrigine in pregnancy. However, enzyme induction in pregnancy demands dose adjustments; where these were not made, nine maternal deaths resulted [116]. A cluster randomised controlled trial (RCT) involving people with dementia in care homes $(n=177)$ found that a pharmacist review of antipsychotic medication reduced antipsychotic prescribing and led to a non-significant reduction in mortality $(28 \% \mathrm{vs.} 35 \%)$, but a worsening of neuropsychiatric symptoms [117] and quality of life measures, particularly negative emotions [118]. However, this unintended consequence of guideline compliance might be confined to the most disturbed, and withdrawal reduces the risk of falls [119]. By capturing all possible problems at regular intervals, ADRe promotes early recognition and reporting and improves our understanding of impact and outcomes.

One unintended outcome of regulatory interventions is to accentuate health inequalities.

Prescription of antipsychotics [74], selective serotonin re-uptake inhibitors (SSRIs) in pregnancy [120], and polypharmacy ( $>9$ medicines) are concentrated amongst more deprived socioeconomic groups [121], leading to concerns that ADRs are contributing to health inequalities [122]. UK primary care is 
characterised by the Inverse Care Law [123], whereby resources are diverted away from areas of social deprivation and the greatest medical need. GPs in the most deprived areas are responsible for more patients and are under greater pressures and risk of burnout [124]. Working under such conditions may prove a barrier to implementation of regulations or warnings: Checks or new restrictions for medicinal products may be overlooked due to the urgency of care. The resources to monitor patients during withdrawal of medication may simply not be there, allowing outdated and suboptimal practices to persist. Therefore, to ensure that the most disadvantaged patients benefit, interventions need to be mandated and inspected. Accordingly, the Welsh Government has asked the Care Homes' Inspectorate to check quarterly medication reviews of antipsychotic prescribing in care homes [62]. Were ADRe to be routinely utilised in this task, it would bring rigour and substance to these reviews. Its person-centred documentation of signs and symptoms will prevent this regulatory intervention being reduced to an audit of medicines' charts.

\section{Conclusions}

The reluctance to de-prescribe is based, in part, on the potential risks of medication withdrawal, and the associated commitment of resources, but perpetuates the 'othering' [18] and control of service users. For some medicines, ADRs are overtly stigmatising and disempowering-such as the agitation, nervousness, and anxiety caused by some antidepressants, and the movement disorders and cognitive impairment caused by antipsychotics. It is incumbent on healthcare professionals to 'do no harm', but the over-reliance on prescriptions can lead to real harm and an imbalance of power. Regulation at system level alone is not enough: Oversight should include comprehensive patient checks for undesirable adverse effects of medicines, however mundane. The ADRe Profile provides a sensible and usable tool to achieve improved patient care and increased understanding of the impact of ADRs.

Supplementary Materials: The following are available online at http:/ /www.mdpi.com/2226-4787/6/3/102/s1, Table S1: Glossary.

Author Contributions: All authors of this article have agreed on the final version of this paper and have met all the following criteria: substantial contributions to conception and design, acquisition of data, or analysis and interpretation of data, drafting the article or revising it critically for important intellectual content.

Funding: This research has received no specific grant from any funding agency in the public, commercial, or not-for-profit sectors.

Acknowledgments: Part of this paper is based on a presentation at the Measuring impact of Pharmacovigilance Information Day on 14 November 2017 at the EMA, Canary Ward, London organised by DIA (develop, innovate advance) for industry delegates: Jordan S Outline of a Process to identify intended (and unintended) public health outcomes of regulatory decisions.

Conflicts of Interest: The authors declare no conflict of interest.

\section{References}

1. McKinlay, J.B.; McKinlay, S.M. The Questionable Contribution of Medical Measures to the Decline of Mortality in the United States in the 20th Century. The Milbank Memorial Fund Quarterly. Health Soc. 1977, $55,405-428$.

2. Weinshilboum, R.M. The Therapeutic Revolution. Clin. Pharmacol. Therap. 1987, 42, 481-484. [CrossRef]

3. Cutler, D.M. Your Money or Your Life: Strong Medicine for America's Health Care System; Oxford University Press: Oxford, UK, 2004.

4. Lesch, J.E. The First Miracle Drugs: How the Sulfa Drugs Transformed Medicine; Oxford University Press: New York, NY, USA, 2007.

5. Schuman, A.J. A Concise History of Antimicrobial Therapy (Serendipity and All). Contemp. Pediatr. 2003, 20, 66-85.

6. Jayachandran, S.; Lleras-Muney, A.; Lleras-Muney, A.; Smith, K.V. Modern Medicine and the Twentieth Century Decline in Mortality: Evidence on the Impact of Sulfa Drugs. Am. Econ. J. Appl. Econ. 2010, 2, 118-146. [CrossRef] 
7. Leucht, S.; Tardy, M.; Komossa, K.; Heres, S.; Kissling, W.; Salanti, G.; Davis, J.M. Antipsychotic drugs versus placebo for relapse prevention in schizophrenia: A systematic review and meta-analysis. Lancet 2012, 379, 2063-2071. [CrossRef]

8. Shen, W.W. A history of antipsychotic drug development. Compr. Psychiatry 1999, 40, 407-414. [PubMed]

9. Zhang, J.-P. The Benefits of Antipsychotic Drugs: Symptom Control and Improved Quality of Life. In Life-Threatening Effects of Antipsychotic Drugs; Manu, P., Flanagan, R.J., Ronaldson, K.J., Eds.; Academic Press: Cambridge, MA, USA, 2016; pp. 295-309.

10. D'Arcy, P.F. Iatrogenic disease: A hazard of multiple drug therapy. R. Soc. Health J. 1976, 96, $277-283$. [PubMed]

11. Stolley, J.M.; Buckwalter, K.C.; Fjordbak, B.; Bush, S. Iatrogenesis in the elderly: Drug-related problems. J. Gerontol. Nurs. 1991, 17, 12-17. [PubMed]

12. Gardner, D.M.; Teehan, M.D. Antipsychotics and Their Side Effects; Cambridge University Press: New York, NY, USA, 2011.

13. Manu, P.; Flanagan, R.J.; Ronaldson, K.J. (Eds.) Life-Threatening Effects of Antipsychotic Drugs; Academic Press: Cambridge, MA, USA, 2016.

14. British Broadcasting Corporation (BBC). The New Jerusalem: Safe in Their Hands (Documentary Produced on 50th Anniversary of UK Postwar Welfare State for BBC 2). 1995. Available online: https: / www.youtube. com/watch? $\mathrm{v}=\mathrm{fKzX}$ CWJsesg (accessed on 13 September 2018).

15. Szczepura, A.; Clay, D.; Nelson, S.; Wild, D.; Spilsbury, K. Improving Care in Residential Care Homes: A Literature Review; Joseph Rowntree Foundation: York, UK, 2008.

16. Banerjee, S. The Use of Antipsychotic Medication for People with Dementia: Time for Action. A Report for the Minister of State for Care Services. An Independent Report Commissioned for the Department of Health. 2009. Available online: http:/ /webarchive.nationalarchives.gov.uk/20130104175837/http:/ / www.dh.gov.uk/prod_ consum_dh/groups/dh_digitalassets/documents/digitalasset/dh_108302.pdf (accessed on 20 August 2017).

17. Sherlaw-Johnson, C.; Crump, H.; Curry, N.; Paddison, C.; Meaker, R. Transforming Health Care in Nursing Homes: An Evaluation of a Dedicated Primary Care Service in Outer East London; Nuffield Trust: London, UK, 2018.

18. Roberts, M.L.A.; Schiavenato, M. Othering in the nursing context: A concept analysis. Nurs. Open 2017, 4, 174-181. [CrossRef] [PubMed]

19. Hoffmann, T.C.; Del Mar, C. Clinicians' Expectations of the Benefits and Harms of Treatments, Screening, and Tests: A Systematic Review. JAMA Intern. Med. 2017, 177, 407-419. [CrossRef] [PubMed]

20. Schork, N.J. Personalized medicine: Time for one-person trials. Nature 2015, 520, 609-611. [CrossRef] [PubMed]

21. Hakkarainen, K.M.; Andersson Sundell, K.; Petzold, M.; Hägg, S. Prevalence and perceived preventability of self-reported adverse drug events—A population-based survey of 7099 adults. PLoS ONE 2013, 8, e73166. [CrossRef] [PubMed]

22. Kanagaratnam, L.; Dramé, M.; Trenque, T.; Oubaya, N.; Nazeyrollas, P.; Novella, J.L.; Jolly, D.; Mahmoudi, R. Adverse drug reactions in elderly patients with cognitive disorders: A systematic review. Maturitas 2016, 85, 56-63. [CrossRef] [PubMed]

23. Alhawassi, T.M.; Krass, I.; Bajorek, B.V.; Pont, L.G. A systematic review of the prevalence and risk factors for adverse drug reactions in the elderly in the acute care setting. Clin. Interv. Aging 2014, 9, 2079-2086. [CrossRef] [PubMed]

24. Bouvy, J.C.; De Bruin, M.L.; Koopmanschap, M.A. Epidemiology of adverse drug reactions in Europe: A review of recent observational studies. Drug Saf. 2015, 38, 437-453. [CrossRef] [PubMed]

25. Deilkås, E.T.; Risberg, M.B.; Haugen, M.; Lindstrøm, J.C.; Nylén, U.; Rutberg, H.; Michael, S. Exploring similarities and differences in hospital adverse event rates between Norway and Sweden using Global Trigger Tool. BMJ Open 2017, 7, e012492. [CrossRef] [PubMed]

26. Tangiisuran, B.; Wright, J.; Van der Cammen, T.; Rajkumar, C. Adverse drug reactions in elderly: Challenges in identification and improving preventative strategies. Age Ageing 2009, 38, 358-359. [CrossRef] [PubMed]

27. Jordan, S.; Gabe-Walters, M.E.; Watkins, A.; Humphreys, I.; Newson, L.; Snelgrove, S.; Dennis, M.S. Nurse-Led Medicines' Monitoring for Patients with Dementia in Care Homes: A Pragmatic Cohort Stepped Wedge Cluster Randomised Trial. PLoS ONE 2015, 10, e0140203. [CrossRef] [PubMed] 
28. Jordan, S.; Vaismoradi, M.; Griffiths, P. Adverse drug reactions, nursing and policy: A narrative review. Ann. Nurs. Pract. 2016, 3, 1050. Available online: http:/ /www.jscimedcentral.com/Nursing/nursing-3-1050.pdf (accessed on 13 September 2018).

29. Motter, F.R.; Fritzen, J.S.; Hilmer, S.N.; Paniz, E.N.; Paniz, V.M. Potentially inappropriate medication in the elderly: A systematic review of validated explicit criteria. Eur. J. Clin. Pharmacol. 2018, 74, 679-700. [CrossRef] [PubMed]

30. Pirmohamed, M.; James, S.; Meakin, S.; Scott, A.K.; Walley, T.J.; Farrer, K.; Park, B.K.; Breckenridge, A.M. Adverse drug reactions as cause of admission to hospital: Prospective analysis of 18820 patients. BMJ 2004, 329, 15-19. [CrossRef] [PubMed]

31. NICE Medicines and Prescribing Centre. Medicines Optimisation: The Safe and Effective Use of Medicines to Enable the Best Possible Outcomes; NICE Guideline 5; NICE: London, UK, 2015; Available online: https://www.nice.org.uk/guidance/ng5/resources/medicines-optimisation-thesafe-and-effective-use-of-medicines-to-enable-the-best-possible-outcomes-pdf-51041805253 (accessed on 20 August 2017).

32. Kongkaew, C.; Noyce, P.R.; Ashcroft, D.M. Hospital admissions associated with adverse drug reactions: A systematic review of prospective observational studies. Ann. Pharmacother. 2008, 42, 1017-1025. [CrossRef] [PubMed]

33. Frontier Economic. Exploring the Costs of Unsafe Care in the NHS: A Report Prepared for the Department of Health. 2014. Available online: http:/ / www.frontier-economics.com/documents/2014/10/exploringthe-costs-of-unsafe-care-in-the-nhs-frontier-report-2-2-2-2.pdf (accessed on 20 August 2017).

34. Elliott, R.; Camacho, E.; Campbell, F.; Jankovic, D.; St. James, M.M.; Kaltenthaler, E.; Wong, R.; Sculpher, M.; Faria, R. Prevalence and Economic Burden of Medication Errors in the NHS in England. Rapid Evidence Synthesis and Economic Analysis of the Prevalence and Burden of Medication Error in the UK. Policy Research Unit in Economic Evaluation of Health and Care Interventions. Universities of Sheffield and York. 2018. Available online: http:/ / www.eepru.org.uk/prevalence-and-economic-burden-ofmedication-errors-in-the-nhs-in-england-2/ (accessed on 18 September 2018).

35. Nair, P.N.; Chalmers, L.; Connolley, M.; Bereznicki, B.J.; Peterson, G.M.; Curtain, C.; Castelino, R.L.; Bereznicki, L.R. Prediction of Hospitalisation due to Adverse Drug Reactions in Elderly Community-Dwelling Patients (The PADR-EC Score). PLoS ONE 2016. [CrossRef]

36. Walter, S.R.; Day, R.O.; Gallego, B.; Westbrook, J.I. The impact of serious adverse drug reactions: A population based study of a decade of hospital admissions in New South Wales, Australia. Br. J. Pharmacol. 2017, 83, 416-426. [CrossRef] [PubMed]

37. WHO. Patient Safety Research: WHO. 2009. Available online: http://apps.who.int/iris/bitstream/10665/ 70145/1/WHO_IER_PSP_2009.10_eng.pdf (accessed on 20 August 2017).

38. Roulet, L.; Ballereau, F.; Hardouin, J.B.; Chiffoleau, A.; Potel, G.; Asseray, N. Adverse drug event nonrecognition in emergency departments: An exploratory study on factors related to patients and drugs. J. Emerg. Med. 2014, 46, 857-864. [CrossRef] [PubMed]

39. Lesser, G.T.; Boockvar, K.; Polsky, I. Underestimation of adverse drug events in nursing home residents. Arch. Intern. Med. 2002, 162, 609-610. [CrossRef] [PubMed]

40. Kongkaew, C.; Hann, M.; Mandal, J.; Williams, S.D.; Metcalfe, D.; Noyce, P.R.; Ashcroft, D.M. Risk factors for hospital admissions associated with adverse drug events. Pharmacotherapy 2013, 33, 827-837. [CrossRef] [PubMed]

41. Rydberg, D.M.; Holm, L.; Engqvist, I.; Fryckstedt, J.; Lindh, J.D.; Stiller, C.O.; Asker-Hagelberg, C. Adverse Drug Reactions in a Tertiary Care Emergency Medicine Ward-Prevalence, Preventability and Reporting. PLoS ONE 2016, 11, e0162948. [CrossRef] [PubMed]

42. Beijer, H.J.; de Blaey, C.J. Hospitalisations caused by adverse drug reactions (ADR): A meta-analysis of observational studies. Pharm. World Sci. 2002, 14, 46-54. [CrossRef]

43. Gabe, M.E.; Davies, G.A.; Murphy, F.; Davies, M.; Johnstone, L.; Jordan, S. Adverse drug reactions: Treatment burdens and nurse-led medication monitoring. J. Nurs. Manag. 2011, 19, 377-392. [CrossRef] [PubMed]

44. Brenner, S.; Detz, A.; Lopez, A.; Horton, C.; Sarkar, U. Signal and noise: Applying a laboratory trigger tool to identify adverse drug events among primary care patients. BMJ Qual. Saf. 2012, 21, 670-675. [CrossRef] [PubMed] 
45. Forster, A.J.; Murff, H.J.; Peterson, J.F.; Gandhi, T.K.; Bates, D.W. Adverse drug events occurring following hospital discharge. J. Gen. Intern. Med. 2005, 20, 317-323. [CrossRef] [PubMed]

46. Gurwitz, J.H.; Field, T.S.; Judge, J.; Rochon, P.; Harrold, L.R.; Cadoret, C.; Lee, M.; White, K.; LaPrino, J.; Erramuspe-Mainard, J.; et al. The incidence of adverse drug events in two large academic long-term care facilities. Am. J. Med. 2005, 118, 251-258. [CrossRef] [PubMed]

47. Steinman, M.A.; Handler, S.M.; Gurwitz, J.H.; Schiff, G.D.; Covinsky, K.E. Beyond the prescription: Medication monitoring and adverse drug events in older adults. J. Am. Geriatr. Soc. 2011, 59, 1513-1520. [CrossRef] [PubMed]

48. Aronson, J.K.; Ferner, R.E. The law of mass action and the pharmacological concentration-effect curve: Resolving the paradox of apparently non-dose-related adverse drug reactions. Br. J. Clin. Pharmacol. 2016, 81, 56-61. [CrossRef] [PubMed]

49. Stewart, R.; Hotopf, M.; Dewey, M.; Ballard, C.; Bisla, J.; Calem, M.; Fahmy, V.; Hockley, J.; Kinley, J.; Pearce, H.; et al. Current prevalence of dementia, depression and behavioural problems in the older adult care home sector: The South East London Care Home Survey. Age Ageing 2014, 43, 562-567. [CrossRef] [PubMed]

50. Bradley, M.C.; Motterlini, N.; Padmanabhan, S.; Cahir, C.; Williams, T.; Fahey, T.; Hughes, C.M. Potentially inappropriate prescribing among older people in the United Kingdom. BMC Geriatr. 2014, 12, 72. [CrossRef] [PubMed]

51. Sköldunger, A.; Fastbom, J.; Wimo, A.; Fratiglioni, L.; Johnell, K. Impact of Inappropriate Drug Use on Hospitalizations, Mortality, and Costs in Older Persons and Persons with Dementia: Findings from the SNAC Study. Drugs Aging 2015, 32, 671-678. [CrossRef] [PubMed]

52. Storms, H.; Marquet, K.; Aertgeerts, B.; Claes, N. Prevalence of inappropriate medication use in residential long-term care facilities for the elderly: A systematic review. Eur. J. Gen. Pract. 2017, 23, 69-77. [CrossRef] [PubMed]

53. Jordan, S. The Prescription Drug Guide for Nurses; Open University Press, McGraw-Hill: Maidenhead, UK, 2008.

54. Masopust, J.; Protopopová, D.; Vališ, M.; Pavelek, Z.; Klímová, B. Treatment of behavioral and psychological symptoms of dementias with psychopharmaceuticals: A review. Neuropsychiatr. Dis. Treat. 2018, 14, 1211-1220. [CrossRef] [PubMed]

55. Ballard, C.; Hanney, M.L.; Theodoulou, M.; Douglas, S.; McShane, R.; Kossakowski, K.; Gill, R.; Juszczak, E.; Yu, L.M.; Jacoby, R. DART-AD investigators. The dementia antipsychotic withdrawal trial (DART-AD): Long-term follow-up of a randomisedplacebo-controlled trial. Lancet Neurol. 2009, 8, 151-157. [CrossRef]

56. Sacchetti, E.; Turrina, C.; Valsecchi, P. Cerebrovascular accidents in elderly people treated with antipsychotic drugs: A systematic review. Drug Saf. 2013, 33, 273-288. [CrossRef] [PubMed]

57. Schneider, L.S.; Tariot, P.N.; Dagerman, K.S.; Davis, S.M.; Hsiao, J.K.; Ismail, M.S.; Lebowitz, B.D.; Lyketsos, C.G.; Ryan, J.M.; Stroup, T.S.; et al. CATIE-AD Study Group. Effectiveness of atypical antipsychotic drugs in patients with Alzheimer's disease. N. Engl. J. Med. 2006, 355, 1525-1538. [CrossRef] [PubMed]

58. Bradley, P.; Willson, A. Achieving prudent healthcare in NHS Wales Wales: Public Health Wales. 2014. Available online: http:/ / www.1000livesplus.wales.nhs.uk/sitesplus/documents/1011/Achieving\%20prudent $\%$ 20healthcare\%20in\%20NHS\%20Wales\%20paper\%20Revised\%20version\%20\%28FINAL\%29.pdf (accessed on 20 August 2017).

59. Older People's Commissioner for Wales. A Place to Call Home. Older People's Commissioner for Wales. 2014. Available online: http://www.olderpeoplewales.com/Libraries/Uploads / A_Place_to_Call_Home_-_A_ Review_into_the_Quality_of_Life_and_Care_of_Older_People_living_in_Care_Homes_in_Wales.sflb.ashx (accessed on 20 August 2017).

60. Older People's Commissioner for Wales. 2018. A Place to Call Home: Impact and Analysis. Older people's Commissioner for Wales. Available online: http:/ / www.olderpeoplewales.com/Libraries/Uploads / A_ Place_to_Call_Home_-_Impact_Analysis_--_Final.sflb.ashx (accessed on 13 September 2018).

61. Thomas, S.; Banner, T. Improving Medicines Use for Care Home Residents; Royal Pharmaceutical Society: Cardiff, UK, 2016; Available online: https:/ / www.rpharms.com/Portals/0/RPS\%20document\%20library/ Open \%20access/Policy\%20statements/improving-medicines-use-for-care-home-residents-(wales).pdf? ver=2016-10-13-162139-760 (accessed on 3 April 2018). 
62. National Assembly for Wales (NAfW). Health, Social Care and Sport Committee 2018 Use of Antipsychotic Medication in Care Homes; National Assembly: Cardiff, UK, 2018; Available online: http:/ / senedd.assembly.wales/documents / s75570/Report\%20-\%20Use\%20of\%20antipsychotic\% 20medication\%20in\%20care\%20homes.pdf (accessed on 21 July 2018).

63. Francis, R. Report of the Mid Staffordshire NHS Foundation Trust Public Inquiry; The Stationery Office: London, UK, 2013. Available online: http://webarchive.nationalarchives.gov.uk/20150407084231/http: / / www.midstaffspublicinquiry.com/report (accessed on 20 August 2017).

64. NICE. 2014 Updated 2017 Managing Medicines in Care Homes. NICE GUIDANCE SC1. Available online: https:/ / www.nice.org.uk/guidance/sc1\# (accessed on 13 September 2018).

65. Andrews, J.; Butler, M. Trusted to Care. An Independent Review of the Princess of Wales Hospital and Neath Port Talbot Hospital at Abertawe Bro Morgannwg University Health Board. Dementia Services Development Centre, The People Organisation. 2014. Available online: http:/ / www.ambulance.wales.nhs.uk/assets / documents /2e459532-3f27-4fc6-8091-6445fb417a63635387689176252637.pdf (accessed on 20 August 2017).

66. Page, A.T.; Clifford, R.M.; Potter, K.; Schwartz, D.; Etherton-Beer, C.D. The feasibility and effect of deprescribing in older adults on mortality and health: A systematic review and meta-analysis. $\mathrm{Br}$. $\mathrm{J}$. Clin. Pharmacol. 2016, 82, 583-623. [CrossRef] [PubMed]

67. Respect Trial Team. Effectiveness of shared pharmaceutical care for older patients: RESPECT trial findings. Br. J. Gen. Pract. 2010, 60, e10-e19. [CrossRef] [PubMed]

68. Forsetlund, L.; Eike, M.C.; Gjerberg, E.; Vist, G.E. Effect of interventions to reduce potentially inappropriate use of drugs in nursing homes: A systematic review of randomised controlled trials. BMC Geriatr. 2011, 11, 16. [CrossRef] [PubMed]

69. Holland, R.; Desborough, J.; Goodyer, L.; Hall, S.; Wright, D.; Loke, Y.K. Does pharmacist-led medication review help to reduce hospital admissions and deaths in older people? A systematic review and meta-analysis. Br. J. Clin. Pharmacol. 2008, 65, 303-316. [CrossRef] [PubMed]

70. Alldred, D.P.; Kennedy, M.C.; Hughes, C.; Chen, T.F.; Miller, P. Interventions to optimise prescribing for older people in care homes. Cochrane Database Syst. Rev. 2016, CD009095. [CrossRef]

71. Viswanathan, M.; Kahwati, L.C.; Golin, C.E.; Blalock, S.J.; Coker-Schwimmer, E.; Posey, R.; Lohr, K.N. Medication therapy management interventions in outpatient settings: A systematic review and meta-analysis. JAMA Intern. Med. 2015, 175, 76-87. [CrossRef] [PubMed]

72. Medicines and Healthcare products Regulatory Agency (MHRA). Antipsychotics: Initiative to Reduce Prescribing to Older People with Dementia. 2012. Available online: https://www.gov.uk/drugsafety-update/antipsychotics-initiative-to-reduce-prescribing-to-older-people-with-dementia (accessed on 13 September 2018).

73. Szczepura, A.; Wild, D.; Khan, A.J.; Owen, D.W.; Palmer, T.; Muhammad, T.; Clark, M.D.; Bowman, C. Antipsychotic prescribing in care homes before and after launch of a national dementia strategy: An observational study in English institutions over a 4-year period. BMJ Open 2016, 6, e009882. [CrossRef] [PubMed]

74. Marston, L.; Nazareth, I.; Petersen, I.; Walters, K.; Osborn, D.P. Prescribing of antipsychotics in UK primary care: A cohort study. BMJ Open 2014, 4, e006135. [CrossRef] [PubMed]

75. Cooper, A.; Edwards, A.; Williams, H.; Evans, H.P.; Avery, A.; Hibbert, P.; Makeham, M.; Sheikh, A.; JDonaldson, L.; Carson-Stevens, A. Sources of unsafe primary care for older adults: A mixed-methods analysis of patient safety incident reports. Age Ageing 2017, 46, 833-839. [CrossRef] [PubMed]

76. Jordan, S.; Knight, J.; Pointon, D. Monitoring adverse drug reactions: Scales, profiles, and checklists. Int. Nurs. Rev. 2004, 51, 208-221. [CrossRef] [PubMed]

77. Jordan, S.; Banner TGabe-Walters, M.; Mikhail, J.; Round, J.; Snelgrove, S.; Storey, M.; Wilson, D.W.; Hughes, D. Nurse-led medicines' monitoring in care homes study protocol: A process evaluation of the impact and sustainability of the Adverse Drug Reaction (ADRe) Profile for Mental Health Medicines. BMJ 2018. [CrossRef]

78. Australian Pharmaceutical Advisory Council. Guidelines for Medication Management in Residential Aged Care Facilities; Commonwealth of Australia: Canberra, Australia, 2002. Available online: http:/ /www.health. gov.au/internet/main/publishing.nsf/Content/nmp-pdf-resguide-cnt.htm/\$FILE/resguide.pdf (accessed on 13 September 2018). 
79. Brodaty, H.; Aerts, L.; Harrison, F.; Jessop, T.; Cations, M.; Chenoweth, L.; Shell, A.; Popovic, G.C.; Heffernan, M.; Hilmer, S.; et al. Antipsychoticm Deprescription for Older Adults in Long-term Care: The HALT Study. J. Am. Med. Dir. Assoc. 2018, 19, 592.e7-600.e7. [CrossRef] [PubMed]

80. Gabe, M.; Murphy, F.; Davies, G.; Russell, I.; Jordan, S. Medication Monitoring in a Nurse-Led Respiratory Outpatient Clinic: Pragmatic Randomised Trial of the West Wales Adverse Drug Reaction Profile. PLoS ONE 2014, 9, e96682. [CrossRef] [PubMed]

81. Jones, R.; Moyle, C.; Jordan, S. Nurse-led medicines monitoring: A study examining the effects of the West Wales Adverse Drug Reaction Profile. Nurs. Stand. 2016, 31, 42-53. [CrossRef] [PubMed]

82. Jordan, S.; Gabe, M.; Newson, L.; Snelgrove, S.; Panes, G.; Picek, A.; Russell, I.T.; Dennis, M. Medication monitoring for people with dementia in care homes: The feasibility and clinical impact of nurse-led monitoring. Sci. World J. 2014, 2014, 843621. [CrossRef] [PubMed]

83. Gabe, M.E.; Jordan, S.E. Development and clinical gains of nurse-led medication monitoring profiles. J. Nurs. Manag. 2014, 22, 331-349. [CrossRef] [PubMed]

84. Jordan, S.; Tunnicliffe, C.; Sykes, A. Minimising Side Effects: The clinical impact of nurse-administered 'side effect' checklists. J. Adv. Nurs. 2002, 37, 155-165. [CrossRef] [PubMed]

85. Jordan, S. Managing Adverse Drug Reactions: An Orphan Task. Developing Nurse-Administered Evaluation Checklists. J. Adv. Nurs. 2002, 38, 437-448. [CrossRef] [PubMed]

86. Jordan, S.; Philpin, S.; Davies, S.; Andrade, M. The biological sciences in mental health nursing: stakeholders' perspectives. J. Adv. Nurs. 2000, 32, 881-891. [CrossRef] [PubMed]

87. Jordan, S.; Hardy, B.; Coleman, M. Medication management: An exploratory study into the role of Community Mental Health Nurses. J. Adv. Nurs. 1999, 29, 1068-1081. [CrossRef] [PubMed]

88. Day, G. Divided and Dividing Wales? Explorations in Geography and Class. In Making Sense of Wales: A Sociological Perspective; Day, G., Ed.; University of Wales Press: Cardiff, UK, 2002; pp. 94-115.

89. World Health Organization (WHO). 2017 WHO Launches Global Effort to Halve Medication-Related Errors in 5 Years. Geneva/Bonn. Available online: http://www.who.int/mediacentre/news/releases/2017/ medication-related-errors/en/ (accessed on 20 August 2017).

90. Drug and Therapeutics Bulletin 2018 What Dose of Paracetamol for Older People? Drug and Therapeutics Bulletin Vol. 56 I No. 6 I June 2018. pp. 68-72. Available online: https:/ / dtb.bmj.com/content/dtb/56/6/69. full.pdf (accessed on 13 September 2018).

91. Jordan, S.; Morris, J.K.; Davies, G.I.; Tucker, D.; Thayer, D.S.; Luteijn, J.M.; Morgan, M.; Garne, E.; Hansen, A.V.; Klungsøyr, K.; et al. Selective Serotonin Reuptake Inhibitor (SSRI) antidepressants in Pregnancy and Congenital Anomalies: Analysis of linked databases in Wales, Norway and Funen, Denmark. PLoS ONE 2016, 11, e0165122. [CrossRef] [PubMed]

92. Willson, A. The problem with eliminating 'low-value care'. BMJ Qual. Saf. 2015, 24, 611-614. [CrossRef] [PubMed]

93. Barber, C.; Gagnon, D.; Fonda, J.; Cho, K.; Hermos, J.; Miller, M. Assessing the impact of prescribing directives on opioid prescribing practices among Veterans Health Administration providers. Pharmacoepidemiol. Drug Saf. 2017, 26, 40-46. [CrossRef] [PubMed]

94. Sackett, D.L.; Rosenberg, W.M.; Gray, J.A.; Haynes, R.B.; Richardson, W.S. Evidence based medicine: What it is and what it isn't. BMJ 1996, 13, 71-72. [CrossRef]

95. Mittal, M.; Harrison, D.L.; Miller, M.J.; Farmer, K.C.; Thompson, D.M.; Ng, Y.T. Have antiepileptic drug prescription claims changed following the FDA suicidality warning? An evaluation in a state Medicaid program. Epilepsy Behav. 2014, 34, 109-115. [CrossRef] [PubMed]

96. Lu, C.Y.; Zhang, F.; Lakoma, M.D.; Butler, M.G.; Fung, V.; Larkin, E.K.; Kharbanda, E.O.; Vollmer, W.M.; Lieu, T.; Soumerai, S.B.; et al. Asthma Treatments and Mental Health Visits After a Food and Drug Administration Label Change for Leukotriene Inhibitors. Clin. Ther. 2015, 37, 1280-1291. [CrossRef] [PubMed]

97. Hazell, L.; Shakir, S.A. Under-reporting of adverse drug reactions: A systematic review. Drug Saf. 2006, 29, 385-396. [CrossRef] [PubMed]

98. De Boissieu, P.; Kanagaratnam, L.; Abou Taam, M.; Roux, M.P.; Dramé, M.; Trenque, T. Notoriety bias in a database of spontaneous reports: The example of osteonecrosis of the jaw under bisphosphonate therapy in the French national pharmacovigilance database. Pharmacoepidemiol. Drug Saf. 2014, 23, 989-992. [CrossRef] [PubMed] 
99. Pariente, A.; Gregoire, F.; Fourrier-Reglat, A.; Haramburu, F.; Moore, N. Impact of safety alerts on measures of disproportionality in spontaneous reporting databases: The notoriety bias. Drug Saf. 2007, 30, 891-898. [CrossRef] [PubMed]

100. Parker, D.; Lawton, R. Judging the use of clinical protocols by fellow professionals. Soc. Sci. Med. 2000, 51, 669-677. [CrossRef]

101. Roland, M. Linking physicians' pay to the quality of care-A major experiment in the United kingdom. N. Engl. J. Med. 2004, 351, 1448-1454. [CrossRef] [PubMed]

102. BMA and NHS Employers. Revisions to the GMS Contract 2006/07 Delivering Investment in General Practice; BMA: London, UK, 2009; Available online: http://www.nhsemployers.org/ / media/Employers / Documents / Primary\%20care\%20contracts/QOF/2006-07/Revisions\%20to\%20the\% 20GMS\%20contract\%20200607\%20-\%20Delivering\%20investments\%20in\%20general\%20practice.pdf (accessed on 13 September 2018).

103. Kendrick, T.; Stuart, B.; Newell, C.; Geraghty, A.W.; Moore, M. Changes in rates of recorded depression in English primary care 2003-2013: Time trend analyses of effects of the economic recession, and the GP contract quality outcomes framework (QOF). J. Affect. Disord. 2015, 180, 68-78. [CrossRef] [PubMed]

104. Barnes, G.D.; Lucas, E.; Alexander, G.C.; Goldberger, Z.D. National Trends in Ambulatory Oral Anticoagulant Use. Am. J. Med. 2015, 128, 1300.e2-1305.e2. [CrossRef] [PubMed]

105. Mohammad, I.; Korkis, B.; Garwood, C.L. Incorporating Comprehensive Management of Direct Oral Anticoagulants into Anticoagulation Clinics. Pharmacotherapy 2017, 37, 1284-1297. [CrossRef] [PubMed]

106. Odom, D.M.; Mladsi, D.M.; Saag, K.G.; Sherif, B.N.; Miles, L.; Ronquest, N.; Wang, J. Relationship between diclofenac dose and risk of gastrointestinal and cardiovascular events: Meta-regression based on two systematic literature reviews. Clin. Ther. 2014, 36, 906-917. [CrossRef] [PubMed]

107. Sukkar, E. Risk of heart problems prompts removal of OTC diclofenac from UK pharmacy shelves. Pharm. J. 2015, 294, 7846. [CrossRef]

108. Singh, R.R.; Nayak, R. Impact of FDA Black Box Warning on Psychotropic Drug Use in Noninstitutionalized Elderly Patients Diagnosed with Dementia: A Retrospective Study. J. Pharm. Pract. 2015, 29, 495-502. [CrossRef] [PubMed]

109. Ryan, A.M.; Krinsky, S.; Kontopantelis, E.; Doran, T. Long-term evidence for the effect of pay-for-performance in primary care on mortality in the UK: A population study. Lancet 2016, 388, 268-274. [CrossRef]

110. European Network of Centres for Pharmacoepidemiology and Pharmacovigilance (ENCePP). Annex 2 to the Guide on Methodological Standards in Pharmacoepidemiology. 2018. Available online: http:/ /www. encepp.eu/standards_and_guidances (accessed on 13 September 2018).

111. Hakobyan, L.; Haaijer-Ruskamp, F.M.; de Zeeuw, D.; Dobre, D.; Denig, P. A review of methods used in assessing non-serious adverse drug events in observational studies among type 2 diabetes mellitus patients. Health Qual. Life Outcomes 2011, 9, 83. [CrossRef] [PubMed]

112. Schoenmakers, T.W.A.; Teichert, M.; Wensing, M.; de Smet, P.A.G.M. Evaluation of Potentially Drug-Related Patient-Reported Common Symptoms Assessed during Clinical Medication Reviews: A Cross-Sectional Observational Study. Drug Saf. 2017, 40, 419-430. [CrossRef] [PubMed]

113. Talbot, J.; Keisu, M.; Stahle, L. Clinical trials-Collecting safety data and establishing the ADR Profile. In Stephens' Detection and Evaluation of Adverse Drug Reactions, 6th ed.; Talbot, J., Aronson, J.K., Eds.; Wiley-Blackwell: Chichester, UK, 2012; pp. 215-290.

114. Gandhi, T.; Burstin, H.; Cook, F.; Puopolo, A.; Haas, J.; Brennan, T.; Bates, D. Drug Complications in Outpatients. J. Gen. Intern. Med. 2000, 15, 149-154. [CrossRef]

115. Weingart, S.; Gandhi, T.; Seger, A.; Seger, D.L.; Borus, J.; Burdick, E.; Leape, L.L.; Bates, D.W. Patient reported medication symptoms in primary care. Arch. Intern. Med. 2005, 165, 234-240. [CrossRef] [PubMed]

116. Lewis, G.; Cantwell, R.; Clutton-Brock, T.; Cooper, G.; Dawson, A.; Drife, J.; Garrod, D.; Harper, A.; Hulbert, D.; Lucas, S.; et al. Saving Mothers' Lives: Reviewing maternal deaths to make motherhood safer: 2006-2008. The Eighth Report of the Confidential Enquiries into Maternal Deaths in the United Kingdom. BJOG 2011, 118 (Suppl. 1), 1-203. 
117. Ballard, C.; Orrell, M.; Sun, Y.; Moniz-Cook, E.; Stafford, J.; Whitaker, R.; Woods, B.; Corbett, A.; Garrod, L.; Khan, Z.; et al. Impact of antipsychotic review and nonpharmacological intervention on antipsychotic use, neuropsychiatric symptoms, and mortality in people with dementia living in nursing homes: A factorial cluster-randomized controlled trial by the well-being and health for people with dementia (WHELD) Program. Int. J. Geriatr. Psychiatry 2015, 173, 252-262. [CrossRef]

118. Ballard, C.; Orrell, M.; Sun, Y.; Moniz-Cook, E.; Stafford, J.; Whitaker, R.; Woods, B.; Corbett, A.; Banerjee, S.; Testad, I.; et al. Impact of antipsychotic review and non-pharmacological intervention on health-related quality of life in people with dementia living in care homes: WHELD-a factorial cluster randomised controlled trial. Int. J. Geriatr. Psychiatry 2017, 32, 1094-1103. [CrossRef] [PubMed]

119. Iyer, S.; Naganathan, V.; McLachlan, A.J.; Le Couteur, D.G. Medication withdrawal trials in people aged 64 years and older: A systematic review. Drugs Aging 2008, 25, 1021-1031. [CrossRef] [PubMed]

120. Jordan, S.; Charlton, R.A.; Tingay, K.; Thayer, D.S.; Davies, G.I.; Morgan, M.; Tucker, D.; Watkins, A.; Gini, R.; Pierini, A.; et al. SSRI use in pregnancy: A study in 6 European databases. The International Marcé Society for Perinatal Mental Health Biennial Scientific Conference, Swansea University, Swansea, Wales, UK. Abstracts from the Marce Society Conference. Arch. Womens Ment. Health 2015, 18, 269-408. [CrossRef]

121. Guthrie, B.; Makubate, B.; Hernandez-Santiago, V.; Dreischulte, T. The rising tide of polypharmacy and drug-drug interactions: Population database analysis 1995-2010. BMC Med. 2015, 7. [CrossRef] [PubMed]

122. Welsh Government. Chief Medical Officer for Wales Annual Report 2015-2016. 2016. Available online: http:/ / gov.wales/docs/dhss/publications/161110cmoreport16en.pdf (accessed on 13 September 2018).

123. Hart, J.T. The inverse care law. Lancet 1971, 1, 405-412. [CrossRef]

124. Pedersen, A.F; Vedsted, P. Understanding the inverse care law: A register and survey-based study of patient deprivation and burnout in general practice. Int. J. Equity Health 2014, 13, 121. [CrossRef] [PubMed]

(C) 2018 by the authors. Licensee MDPI, Basel, Switzerland. This article is an open access article distributed under the terms and conditions of the Creative Commons Attribution (CC BY) license (http:/ / creativecommons.org/licenses/by/4.0/). 